Article

\title{
Common Reed for Thatching in Northern Germany: Estimating the Market Potential of Reed of Regional Origin
}

\author{
Lea Becker, Sabine Wichmann and Volker Beckmann *iD \\ Faculty of Law and Economics \& Institute of Botany and Landscape Ecology, University of Greifswald, \\ Soldmannstr. 15, D-17489 Greifswald, Germany; leabecker@hotmail.de (L.B.); \\ wichmann@uni-greifswald.de (S.W.) \\ * Correspondence: volker.beckmann@uni-greifswald.de; Tel.: +49-3834-420-4122
}

Received: 1 October 2020; Accepted: 12 December 2020; Published: 16 December 2020

check for updates

\begin{abstract}
Reed has a long tradition as locally available thatching material, but nowadays thatch is a globally traded commodity. Germany and other major importing countries such as the Netherlands, the United Kingdom, and Denmark rely on high import rates to meet the national consumption. This study aimed at providing a detailed picture of the thatching reed market in Northern Germany and at assessing the market potential for reed of regional origin. A written survey among all thatchers in Northern Germany was carried out in 2019, arriving at an effective sample of 47 out of 141 companies. The results revealed that for the responding companies the majority of the reed (59\%) was used for rethatching roofs completely, $24 \%$ for newly constructed roofs, and $17 \%$ for roof repairs. Reed from Germany held a low share of $17 \%$ of the total consumption in 2018. Own reed harvesting was conducted by less than $9 \%$ of the responding companies and given up during the last decades by another $26 \%$. The total market volume of reed for thatching in Northern Germany was estimated for 2018 with a $95 \%$ confidence interval at $3 \pm 0.8$ million bundles of reed with a monetary value at sales prices of $€ 11.6 \pm 2.8$ million. Based on the end consumer demand, the supply gap for reed of regional or German origin was estimated at 523,000 $\pm 392,000$ bundles of reed equaling a market value of $€ 1.9 \pm 1.4$ million, indicating high uncertainties. Most of the responding thatchers $(70 \%)$ did not promote reed of regional origin, mainly due to insufficient availability but also a lack in quality was reported. The cultivation of reed in paludiculture, i.e., as climate-smart land use alternative to drainage-based agriculture on peatlands, can increase the availability of thatching reed in Germany and simultaneously reduce GHG emissions.
\end{abstract}

Keywords: Phragmites australis; thatching companies; value chain; market analysis

\section{Introduction}

Common reed (Phragmites australis) is one of the most widespread plants in the world and populates wetlands of various kinds [1]. Since time immemorial, people made use of different parts of the plant as well as of the reedbed itself [2]. A wide range of historical uses up to services appreciated only recently is described by Haslam [2], Kiviat [3], and Köbbing et al. [4]. While reed is an important resource for the pulp and paper industry in China [5,6], in Europe it is appreciated as building material.

The utilization of the long and thin reed culms as roofing material, i.e., for thatching, is one of the best known and most common applications in many European countries. In Germany, evidence for the use of reed for thatching comes from as early as $4000 \mathrm{BC}$, when the first Neolithic farmers settled at the coastline of the North and Baltic Sea [7]. Until today, thatched houses are commonly found in the coastal regions of Northern Germany and in regions with many inland lakes where they have a 
landscape-defining character. The thatcher's craft is included in the German Inventory of Intangible Cultural Heritage [8]. Thatched houses are valued for providing a pleasant living climate, for the renewable building material, and for its high aesthetic value [8,9]. An average estimate for the durability of a reed thatched roof is 40-50 years with possibly much longer lifetime for the Eastern or Northern side of the roof and very steep roofs [7]. Single cases of considerably shorter lifetimes are known as early or premature decay and have been described for reed thatched houses at least since the 1970s [10] but were increasingly observed in Germany at the turn to the 21st century [11]. The lifetime of a roof is influenced by many factors starting from the quality of the reed, over the construction of the roof up to the maintenance of the thatched roof. Repair work can be necessary from time to time as well as renewing parts especially exposed to wind and weather, like the roof ridge, which needs to be conducted normally every 15-20 years [12]. Every landscape has a traditional regional building and thatching culture with specific house types, roof shapes, or materials used for the roof ridge, e.g., variations of the Low German house, the Haubarg of the Eiderstedt peninsula, or log houses in the Spreewald [12]. Today, reed is not only used for rethatching historical monuments but also on newly build (holiday) houses and even for modern architecture, e.g., exploring the use of thatch for covering walls $[13,14]$.

Despite its long tradition as locally available roofing material, reed for thatching is nowadays an internationally traded commodity. A first analysis of the European market identified major importing countries (the Netherlands, Germany, the United Kingdom, and Denmark) relying on imports of up to $85 \%$ of the national consumption [15]. One major reason of the low self-supply rate is the decline of reedbeds due to dyke construction, drainage, and cultivation of peatland and marsh land [12]. Additionally, the remaining reedbeds are defined as legally protected habitat by the Federal Nature Conservation Act in Germany and partly located in designated nature conservation areas. While the use of domestic resources has been increasingly restricted, reed was imported from East and Southeast Europe (e.g., Hungary, Romania) and since 2005 even from China [15]. The cultivation of reed as agricultural crop might improve the supply with domestic reed.

Common reed is considered as a promising paludicultural plant [16]. Paludiculture is defined as agriculture and forestry on wet or rewetted peatlands; it combines a productive use with the preservation of the peat body as long-term carbon store [17]. There is a high need to develop climate smart utilization options for rewetted peatlands. In Germany, drained peatlands encompass only $7 \%$ of the agricultural area but emit $37 \%$ of the national greenhouse gas emissions of agriculture and agricultural land use; in the EU 3\% of the area are responsible for $25 \%$ of the emissions [18]. Being an emergent wetland plant, reed grows well at water levels near surface, which are needed to ensure peat preservation. In addition to reducing a large source of soil born GHG emissions, below-ground biomass may form new peat thus acting as sink for carbon captured from the atmosphere. Comparing three utilization options for reed, the harvest for thatching was the most profitable option compared to combustion and biogas generation [19]. When it comes to economic viability, the market potential of domestic reed plays an important role.

The research aimed at determining the market volume and market potential of reed of regional origin for thatching in Northern Germany. Specifically, it aimed to answer the following three research questions:

1. What is the current market volume of reed for thatching in Northern Germany?

2. What are the market shares of thatching reed from different origins?

3. What factors influence the demand and supply of reed of regional origin and how can its market potential be assessed?

In answering these questions, we add to the very sparse literature on reed markets and provide the first in-depth study on the market of thatching reed not only in Northern Germany but worldwide. The total quantity, the origin of reed, and quality attributes are investigated as key factors. The results are relevant beyond the scope of Northern Germany as similar situations, i.e., a high consumption of 
reed and a little self-supply rate, are found in other countries, in particular in the Netherlands, Denmark, and the United Kingdom. Furthermore, rewetting of peatlands and identifying economically viable utilization options is an issue worldwide in order to enhance nature-based climate solutions [20,21].

\section{Materials and Methods}

\subsection{Study Site}

Reed thatched houses are found mainly in the North of Germany, i.e., near the coasts, on the islands of the North Sea and the Baltic Sea, but also in areas rich of inland water like the "Spreewald" region south of Berlin [12]. In Southern Germany, the formerly rye straw thatched houses in the Black Forest are also thatched with reed that is nowadays more easily available than long straw [12]. We focused our study on Northern Germany since reed roofed houses are most common in this region. Only few thatched houses are present in the remaining parts of Germany, although straw thatch was a widespread roofing material of rural areas until the beginning of the 20th century [12]. The study region consists of the federal sates of Mecklenburg-Western Pomerania, Lower Saxony, Schleswig-Holstein, Brandenburg, Hamburg, and Bremen, the last two being city states (Figure 1).

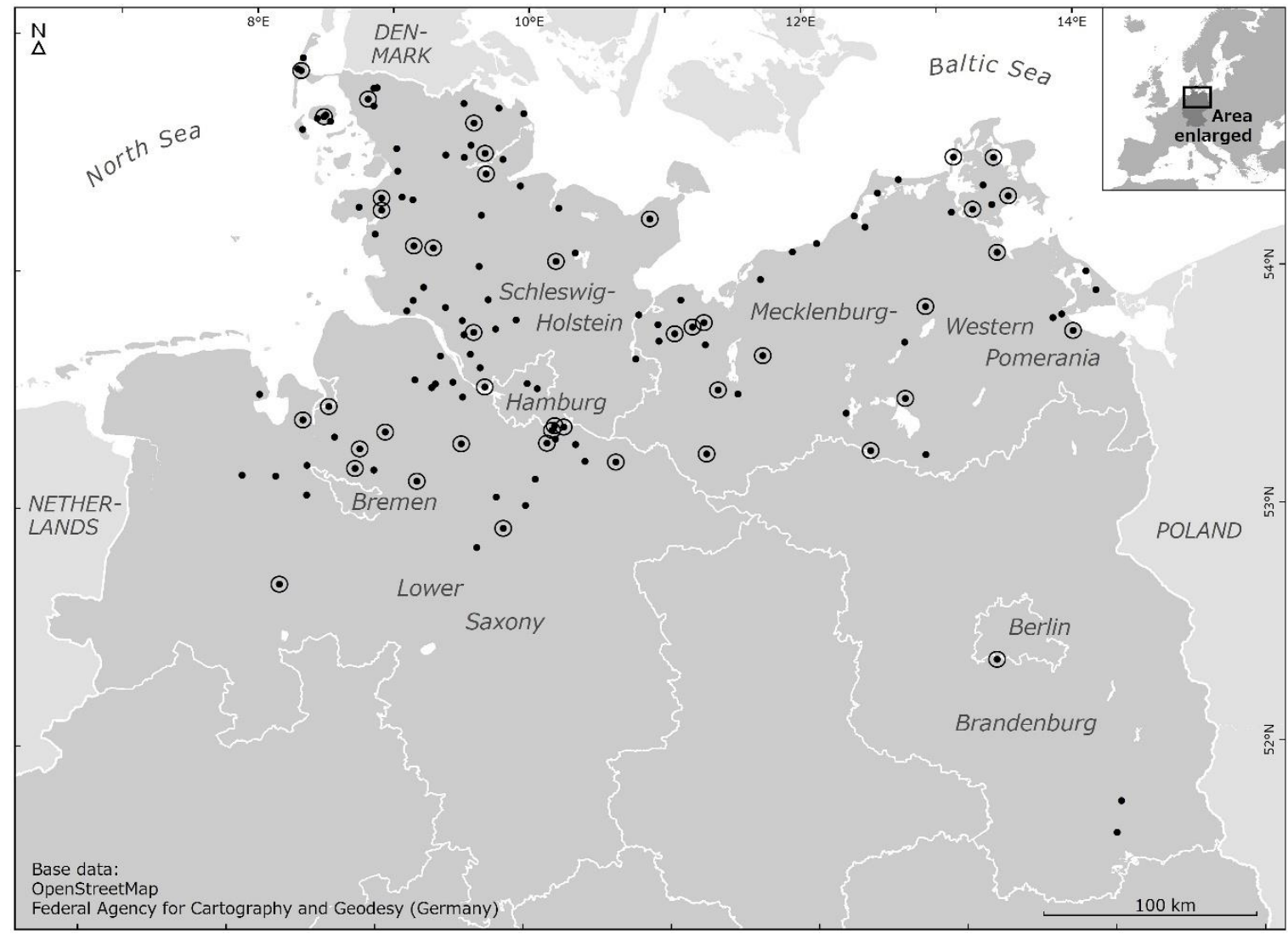

Figure 1. Northern federal states of Germany and the location of sampled (all dots) and responding (large dots) thatching companies.

\subsection{Market Analysis}

The analysis of the market of reed for thatching and the market potential of regional reed builds upon the concept of value chains [22,23] and product differentiation by country or regions of origins [24]. Figure 2 depicts the value chain and the main actors along the chain. The material flow goes from left to right, and the value grows accordingly with every step in the chain; the money-flow goes from right to left. Reed grows either in natural reed beds or is cultivated for being harvested. Cultivation may range from some management decisions taken by the landowner or the land user for existing reed 
beds (e.g., water management) up to the establishment of new reed beds by planting. In Germany, public authorities decide if, when, and how reed harvest can take place. Reed cutters harvest dry winter reed using simple or advanced technologies. Reed is tied and stored for further drying up. It is cleaned and retied to standardized bundles ready for thatching. A reed bundle, also referred to as a Euro bundle has a circumference of $60 \mathrm{~cm}$ [25]. The final demand for thatched houses generates the demand for thatching, the partial demand for trading, the partial demand for cleaning and retying, the partial demand for harvesting, and the partial demand for commercially used reed beds.
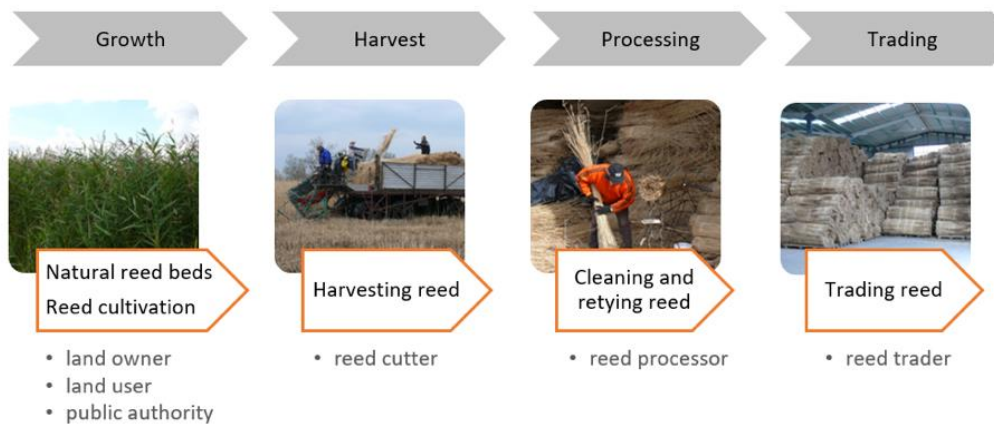

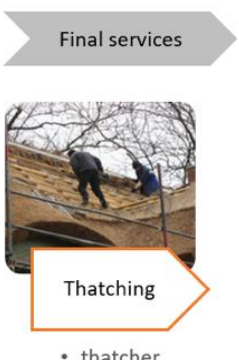

- thatcher

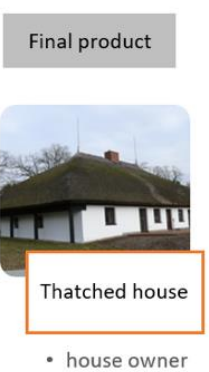

- house owner

Figure 2. Value chain for reed as thatching material and value chain actors.

In this study, we focused on thatching companies being the key actors in the value chain by linking the final demand with the market for raw materials. Addressing thatching companies allowed us to estimate the total market volume for thatching reed (either in physical units of reed bundles or in monetary volume), the origin of reed used, as well as the market share distribution according to origins and among companies. Concerning the market of thatching services, we distinguished three different market segments: thatching new buildings, renewing roofs on old buildings, and repair work on thatched roofs. Thatchers are also able to assess different demands of the final consumer and create a demand for reed of different quality and origins by promotion and price policies. Similar to research that has been conducted for food, e.g., [26], we investigated the importance of reed of regional origin concerning e.g., current market share, demand from end consumer side, valuation of thatcher's side, availability, and market potential.

\subsection{Survey of Thatching Companies}

Surveys are well established instruments in market research in particular for gaining information on size and structure of markets and on the use of and attitudes to products [27]. The target population of this study were thatchers in Northern Germany. After extensive internet and business research a total number of 151 companies were identified. The whole identifiable population was sampled with a combined mail and internet questionnaire using the web-based software tool "EvaSys". To optimize data collection and quality assurance, the questionnaire was subjected to two rounds of pretests [28]. The survey was conducted in August 2019. The questionnaire and a cover letter with additional information were sent to 151 companies requesting participation either in a postal way (a stamped, self-addressed envelope was included) or in an online questionnaire via "EvaSys". One week after initial survey invitation, reminding took place via email or phone.

Because the questionnaire was sent to the entire identifiable population, a census approach was used. Ten businesses no longer existed, were not thatching any more, or were pure trading companies. These businesses were excluded. The population (N) finally included 141 thatching companies. Over the entire three-week response period (30 July-16 August 2019), 47 questionnaires were completed and returned. The response rate was thus $33 \%$. The response rate for the individual federal states was between 24 and $100 \%$ (Table 1). 
Table 1. Total number of sampled companies and response rates in the survey of thatchers in the federal states of Northern Germany carried out in 2019.

\begin{tabular}{ccccc}
\hline \multirow{2}{*}{ Federal State } & \multirow{2}{*}{$\begin{array}{c}\text { Total Number of } \\
\text { Companies }\end{array}$} & \multicolumn{3}{c}{ Response Rate } \\
\cline { 3 - 5 } & & Number & Row Percent & Sample Percent \\
\hline Schleswig-Holstein & 58 & 14 & 24.1 & 29.8 \\
Lower Saxony & 37 & 13 & 35.1 & 27.7 \\
Mecklenburg-Western Pomerania & 39 & 16 & 41.0 & 34.0 \\
Hamburg & 4 & 2 & 50.0 & 4.3 \\
Brandenburg & 2 & 1 & 50.0 & 2.1 \\
Bremen & 1 & 1 & 100.0 & 2.1 \\
\hline Sum & 141 & 47 & 33.3 & 100.0 \\
\hline
\end{tabular}

\subsection{Nonresponses, Representativity and Data Integrity}

Not returned questionnaires, i.e., Unit-Nonresponses, are traditionally explained by "not-at-homes, "people unable to answer" (e.g., being actually ill), and "refusals" (e.g., cost of answering is higher than the expected benefit) $[29,30]$. For the present study, the first and second reason are unlikely due to the conduction of a written survey with a response period of several weeks. Some of the refusing thatchers provided their individual reason for not completing the survey like "no time", "not participating in surveys", "no interest", and "work only little with reed". We assume nonresponses to be random. No systematic bias could be observed, e.g., both very small and very large companies participated in the survey. Due to the lack of any information on the population of thatchers from other sources, the representativity of the sample cannot be assessed directly. Thus, by using the responses for extrapolating data to the total population we need to assume the effective sample being representative for thatchers in Northern Germany. The extrapolated data can partly be crosschecked with data from other sources.

Before conducting the data analysis, the data quality was checked. None of the questionnaires had to be discarded. A few obviously unrealistic values (outliers, inconsistency of values for dependent variables) were excluded from the analysis. Missing values occurred due to Item-Nonresponses or discarded answers. Listwise deletion, i.e., deleting complete cases due to missing values, was not an option due to the small sample size. Missing values were not replaced with substituted values (data imputation). Because all questionnaires were kept for analysis and no data imputation was conducted, the number of effectively sampled companies (n) differed depending on the analyzed question.

Unit- and Item-Nonresponses, even if occurring completely at random, always reduce the effective sample size and increase the sampling error and the variance of the estimates [31]. Taking this into account, we estimated the main extrapolated variables of interest at a confidence interval of $95 \%$.

\subsection{Data Analysis}

\subsubsection{Quantitative Analysis}

For most variables basic descriptive statistics are reported, including mean $(\mathrm{M})$, standard deviation (SD), sum, and sometimes min and max values. Histograms are presented only for the most important variables. For the purpose of extrapolation, we checked whether or not differences in the distribution of variables between companies located in different federal states exist. Only those federal states were compared in which the number of responses to the questionnaires was high enough to allow valid statistical statements to be made, i.e., Schleswig-Holstein, Lower Saxony, and Mecklenburg-Western Pomerania. Because the data were not normally distributed and differences between independent samples were to be investigated, the Kruskal-Wallis test was applied in each case [32]. In addition, the sale-price differences between imported reed and reed from Germany were to be checked for their statistical significance in companies that offer both types of reed. Because these data were not normally distributed either, a Wilcoxon matched pair signed rank-Test was used [32]. Furthermore, 
a Fisher-exact test was carried out to identify a possible correlation between the promotion and the quality assessment of reed of regional origin. A linear regression analysis (ordinary least squares-OLS) was performed to check the relationship between the number of orders for thatching and the number of bundles installed. The values of a dependent variable (in this case the number of bundles installed in 2018) are to be traced back to independent variables (here the different orders). The statistical analysis of the data was conducted with the Statistical Package for Social Sciences (SPSS, Armonk, NY, USA). In all calculations, the level of statistical significance was set to $p \leq 0.05$ [33].

We calculated sampling errors to estimate the extent of the variation that is due to investigating a sample but not the whole population. The $95 \%$ confidence intervals $(C I)$ for the expected population means $(\mu)$ were determined by using the following formula:

$$
C I(\mu)=M \pm z_{\alpha / 2} \frac{S D}{\sqrt{n}} \sqrt{\frac{N-n}{N-1}}
$$

where $M$ indicates the sample mean, $z_{\alpha / 2}$ the $z$-value for $\alpha=5 \%$, that is $1.96, S D$ the sample standard deviation, $n$ the sample size, $N$ the population, and $\sqrt{N-n / N-1}$ the finite population correction factor [34]. For further mathematical procedures, rules for expected value calculation and propagation of uncertainties were applied [35].

\subsubsection{Qualitative Analysis}

Two open questions were asked concerning the promotion and the availability of reed of regional origin leading to qualitative statements. Inductive coding is one of the forms of content analysis defined by [36]. Instead of being based on theoretical assumptions, the inductive procedure uses only the available material as a starting point for category formation. Inductive coding was suitable for the survey, since the lack of literature required an exploratory approach.

Because the quality of the results depends directly on the decisions of the rater, coding was accomplished independently by two raters and the coding was compared to check the quality of the category system. SPSS was used to calculate the measure for the randomly corrected agreement Cohens Kappa $[33,36]$. Cohens Kappa calculates the correspondence of the category assignment of text parts between the two raters and relativizes this by the probability of a random match [37]. The higher the agreement between the raters, the more independent are the results of the raters. In the calculation, the categorization of the answers to the question why reed of regional origin is not promoted resulted in a kappa of $k=0.951$ and the question why the demand for reed of regional origin cannot be met resulted in a kappa of $\kappa=0.853$. Both kappas correspond to a very high match [38]. In the end, the two raters agreed upon a uniform category allocation for text parts that had been assigned to different categories, which formed the basis for the analysis of the frequencies in the results section.

\subsection{Cross Validation}

To validate the information of the survey, the results were compared with information about roofing standards and available trade data. The estimated number of bundles of reed used for thatching new and renewed roofs were compared with information on average roof sizes and average number of bundles used per square meter. The results of the stated origin of the bundles used by the thatchers was compared with the import figures on the EU portal "Eurostat" for 2018. For the latter purpose, the database "Eurostat" was called up [39]. Then, the database for international data (detailed data) was selected. The import of reed can be found in the EU trade to CN8 in 2018 under the products G14. Reed is classified under the trade code "1401 9000 ". It is assumed that the other products covered by this code, e.g., raffia for plaiting, are of negligible importance [15]. The EU countries (EU28 INTRA), as well as Ukraine, Turkey, Belarus, and China were selected as partner countries and Germany as reporter for imports. The selection is based on the countries listed in the reed product 
data sheet [25]. As in the questionnaire, the comparative figures include Turkey, Belarus, and Ukraine as European imports.

\section{Results}

\subsection{Thatching Companies}

Most of the responding thatching companies are specialized on thatching. About two thirds of the companies $(62 \%, n=29)$ work with reed as the only roofing material, while $38 \%(n=18)$ also use other materials. Some specialized thatchers are also trading reed $(n=2)$, harvesting reed $(n=4)$, or cultivating reed $(n=1)$. In terms of employment, all thatching companies can be classified as small and medium scale enterprises (SME) ranging from pure self-employment to a maximum of 28 full-time employees. On average, the companies employ almost six full-time employees $(\mathrm{SD}=5.53)$. Part-time employment $(n=15)$ and seasonal employment $(n=4)$ are not very common. While $26 \%(n=12)$ of the companies provided thatching services only in their local district, $11 \%(n=5)$ covered all categories reaching from local district over other districts of their federal state to other federal states and even other countries. Services were provided for instance in the Netherlands, Belgium, Luxemburg, France, Great Britain, Ireland, Poland, Sweden, and Iran. In summary, the responding thatching companies in Northern Germany can be characterized as small and medium scale enterprises with a high level of specialization and a permanent labor force. The market orientation ranges between a very local market and a European market dominated by a regional and national market orientation.

\subsection{Thatching Services and Market Development}

The final market for thatching services can be divided into three market segments (1) thatching new roofs, (2) renewal of roofs, and (3) repair of roofs. Table 2 shows the number of orders carried out by responding thatchers in 2018. A total of 83 roofs were newly built and 231 roofs were completely renewed. There were also 1778 orders to repair a thatched roof. On average, one company carried out around 2 orders to cover newly built thatched roof houses, 6 orders for complete renovation, and 47 repairs. The SD indicates that there is a large variation for orders across companies, especially for repairs.

Table 2. Types of orders for thatching services of responding thatching companies in Northern Germany in 2018.

\begin{tabular}{ccccc}
\hline \multirow{2}{*}{ Type of Order } & \multirow{n}{*}{$\mathbf{n}$} & \multicolumn{3}{c}{ Number of Orders } \\
\cline { 3 - 5 } & & Sum & Mean & SD \\
\hline Newly constructed roofs & 40 & 83 & 2.1 & 3.8 \\
\hline Completely renewed roofs & 40 & 231 & 5.8 & 5.7 \\
\hline Repairs of roofs & 38 & 1778 & 46.8 & 62.4 \\
\hline
\end{tabular}

Thatchers were asked how they rate the development of the market for newly constructed roofs in the ten years before 2018 on a scale of 1-7, where 1 indicated greatly reduced and 7 greatly increased. Overall, the frequency of newly thatched houses in the past 10 years was assessed as slightly increasing $(\mathrm{n}=41, \mathrm{M}=4.4, \mathrm{SD}=1.7)$. Thatchers were also asked how they assess the development of general roofing market relative to the thatching market on a Likert-Scale from 1-much worse to 7 -much better. On average, the general market for roofing was considered to have developed slightly better $(\mathrm{n}=46, \mathrm{M}=5, \mathrm{SD}=1.6)$.

\subsection{Reed Bundles Per Company and for Thatching Services}

The thatchers were asked how many Euro bundles of reed they installed in 2018. The distribution is depicted in Figure 3. Most of them installed less than 10,000 bundles with a minimum of 200 and a 
maximum of 80,000 bundles. For the sample of 35 respondents, a total of 750,575 bundles of reed were installed $(\mathrm{M}=21,445, \mathrm{SD}=19,964)$.

In order to link the number of orders for thatching with the amount of reed, a linear regression through the origin was carried out $(n=30)$. The regression estimated that 2132 bundles $(p<0.000)$ were installed for each newly built house, 1923 bundles for each completely renewed roof $(p<0.000)$, and 24 bundles for each repair $(p=0.521)$. Overall, the number of orders significantly influenced how many bundles of reed were installed in $2018(\mathrm{~F}=40.2, p<0.000)$. The regression explains $82 \%$ of the variance in the installed bundles. It should be noted that the repairs were not statistically significant, obviously, since the area size per order can vary greatly.

Thus, in terms of reed bundles used, the market for completely renewed roofs is estimated to be the largest (59\% of the annually installed reed), followed by newly constructed roofs (24\%), and finally roof repairs $(17 \%)$, if the latter includes the residuals.

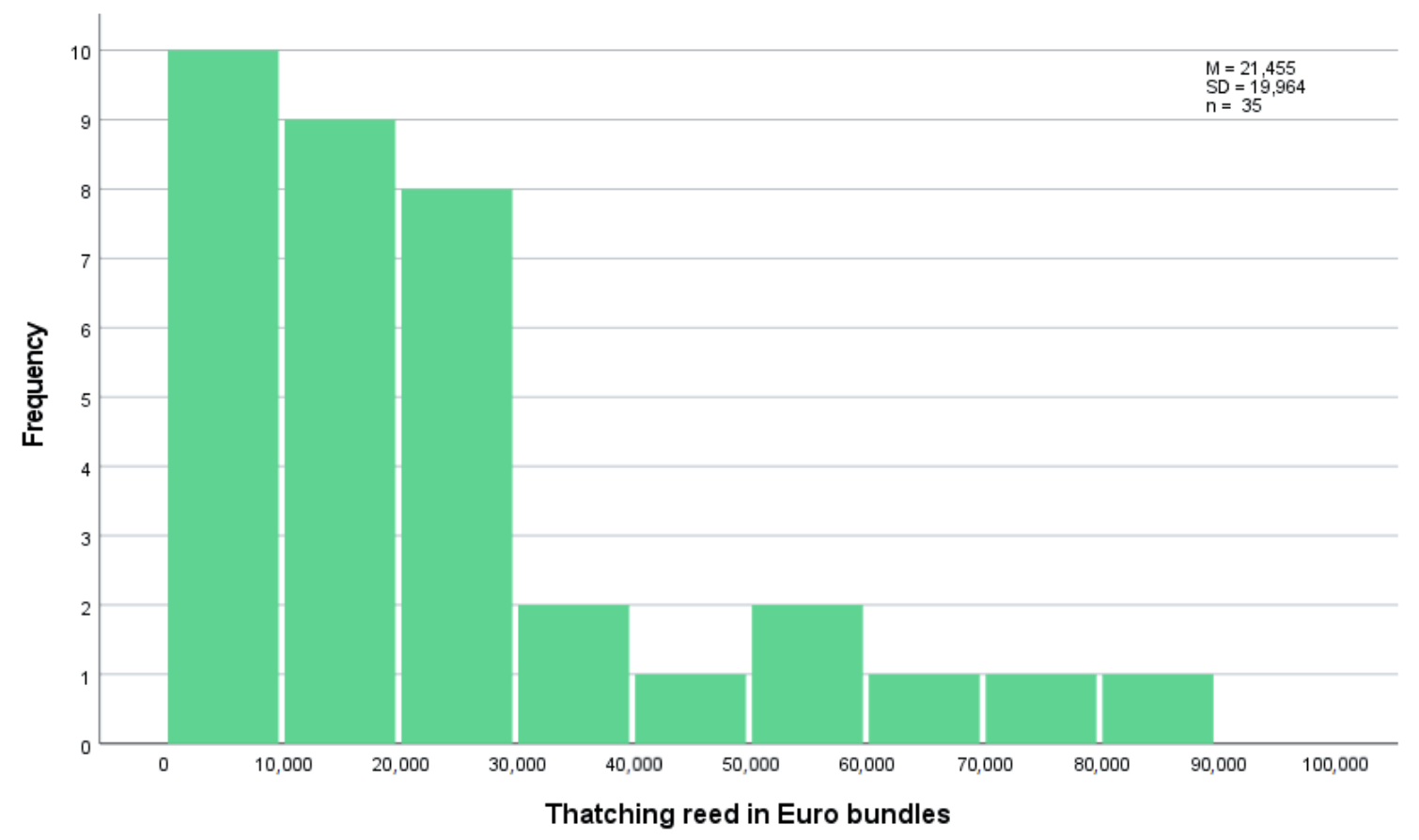

Figure 3. Quantity of Euro bundles of reed installed for thatched houses per responding thatching company in Northern Germany in $2018(n=35)$.

The results of the linear regression of the orders and installed bundles can be compared with the size of a roof and thus validated. The roof area of a single-family house in Germany is approximately $150 \mathrm{~m}^{2}$ [40]. At least 12 bundles of thatch are required to cover one square meter of roof $[7,41,42]$. If the roof area is now calculated using the number of bundles installed per order, this amounts to an average of $178 \mathrm{~m}^{2}$ for newly built houses and an average of $161 \mathrm{~m}^{2}$ for renovated houses. Because these are realistic sizes, it can be assumed that the data given are consistent.

\subsection{Market Shares by Origins of Thatching Reed}

Thatchers were asked where the thatch came from in 2018. As can be seen in Table 3, the respondents indicated that $12.8 \%$ came from their respective federal state and a further $4.1 \%$ from other parts of Germany. A total of $4.3 \%$ came from the Polish part of Pomerania, i.e., the neighboring region of Mecklenburg-Western Pomerania, and the main part came from the remaining European market with $62.7 \%$. In addition, $16.1 \%$ of the reed was imported from China. 
Table 3. Origins of thatching reed used by responding thatching companies in Northern Germany in $2018(\mathrm{n}=44)$.

\begin{tabular}{ccc}
\hline \multirow{2}{*}{ Origins } & \multicolumn{2}{c}{ Percentage of Reed } \\
\cline { 2 - 3 } & Mean & SD \\
\hline The respective federal state & 12.8 & 25.1 \\
\hline Other parts of Germany & 4.1 & 13.9 \\
\hline Polish part of Pomerania & 4.3 & 13.2 \\
\hline Other parts of the European market (including Ukraine and Turkey) & 62.7 & 40.0 \\
\hline China & 16.1 & 28.9 \\
\hline
\end{tabular}

For validation, the information on the origin of reed for thatched roofs in Northern Germany can be compared with EU import statistics from 2018. Of the 6367 tons of reed imported to Germany, $80 \%$ came from the European domestic market (EU28 intra, Belarus, Turkey, and Ukraine) and 20\% from China. The imports make up $100 \%$ of the reed used. For comparing these figures with the information from the questionnaire, the share of nonimported reed (17\%) must be included. Considering an import rate of $83 \%$, EU trade statistics reveal $66 \%$ of the reed coming from the European market and $17 \%$ from China. In comparison to the information provided by thatchers $(67 \%$ from the European market, including the Polish part of Pomerania, and 16\% from China), the percentage figures hardly differ.

\subsection{Thatching Reed Sales Prices and Origins}

Thatchers were asked for the price at which a Euro bundle is sold to the customer (Table 4). The thatchers stated that a Euro bundle of reed imported to Germany was sold to their customers for an average price of $€ 3.90$, while a Euro bundle of reed from Germany cost on average $€ 3.57$.

Table 4. Customer purchasing prices of thatching reed sold by responding thatching companies (in prices of 2018).

\begin{tabular}{cccccc}
\hline \multirow{2}{*}{ Origin } & \multirow{n}{*}{} & \multicolumn{4}{c}{ €/Euro Bundle } \\
\cline { 3 - 6 } & & Mean & SD & Min & Max \\
\hline Germany & 25 & 3.57 & 0.87 & 2.5 & 5.5 \\
Other countries & 38 & 3.9 & 0.94 & 2.41 & 6.5 \\
\hline
\end{tabular}

For companies selling reed from Germany as well as from other origins ( $\mathrm{n}=24)$, a Wilcoxon matched pair signed rank-Test indicated that thatching reed from Germany is offered at a significant slightly lower price $(p=0.037)$.

\subsection{Purchasing Criteria of Thatchers}

When purchasing reed, the origin of reed is a relevant criterion for $54 \%$ of the thatchers (Table 5). However, other criteria are more important. All thatchers stated that quality is an important purchasing criterion for them. Quality requirements for thatch according to the "Product data sheet for thatch" published by the "German roofing association" include: cleanliness, culm length, and breaking strength [25]. These criteria were considered as relevant by $91 \%, 87 \%$, and $70 \%$ of the thatchers, respectively. In a question, where the thatchers should rank the three most important criteria, quality was the most important criterion for $56 \%$ and the second most important criterion for another $10 \%(n=43)$. Origin was the most important criteria only for one thatcher $(2 \%)$, and the second most important for three $(7 \%)$.

Interestingly, price was a relevant criterion only for about one third of the responding thatchers. No thatcher mentioned price as the most important criterion; however, four thatchers mentioned price as the second and another three as the third most important criterion. Color of reed was least important. 
Table 5. Criteria when purchasing reed for thatching of responding thatching companies in Northern Germany in descending order $(n=46)$.

\begin{tabular}{ccc}
\hline Criteria & Frequency & Percent \\
\hline Quality & 46 & 100.0 \\
\hline Cleanliness & 42 & 91.3 \\
\hline Culm length & 40 & 87.0 \\
\hline Breaking strength & 32 & 69.6 \\
\hline Culm wall thickness & 26 & 56.5 \\
\hline Origin & 25 & 54.3 \\
\hline Price & 15 & 32.6 \\
\hline Storage and transportation & 27 & 29.6 \\
\hline Color & 9 & 19.6 \\
\hline
\end{tabular}

\subsection{Regional Origin of Thatching Reed and Quality}

Regional origin is a fussy concept. Therefore, the thatchers were asked at first how do they understand the term "regional" in relation to reed. For the responding thatchers, "regional" primarily means reed from Germany (33\%), from their own federal state (28\%), and from their own district $(26 \%)(n=47)$. For only 5\%, "regional" means from the entire European Single Market. As we had anticipated those diverse concepts of regionality, all further questions on regional reed applied a uniform definition: "Regional reed include all reed from a radius of up to $150 \mathrm{~km}$ ".

Thatchers were asked how they assess the quality of regional reed as compared to other sources (Figure 4). On average the quality was assessed as equal. Of the respondents $(\mathrm{n}=37), 10$ thatchers considered the quality as superior and 14 as inferior. All thatching companies that were engaged in harvesting reed $(n=4)$ considered regional reed of superior quality.

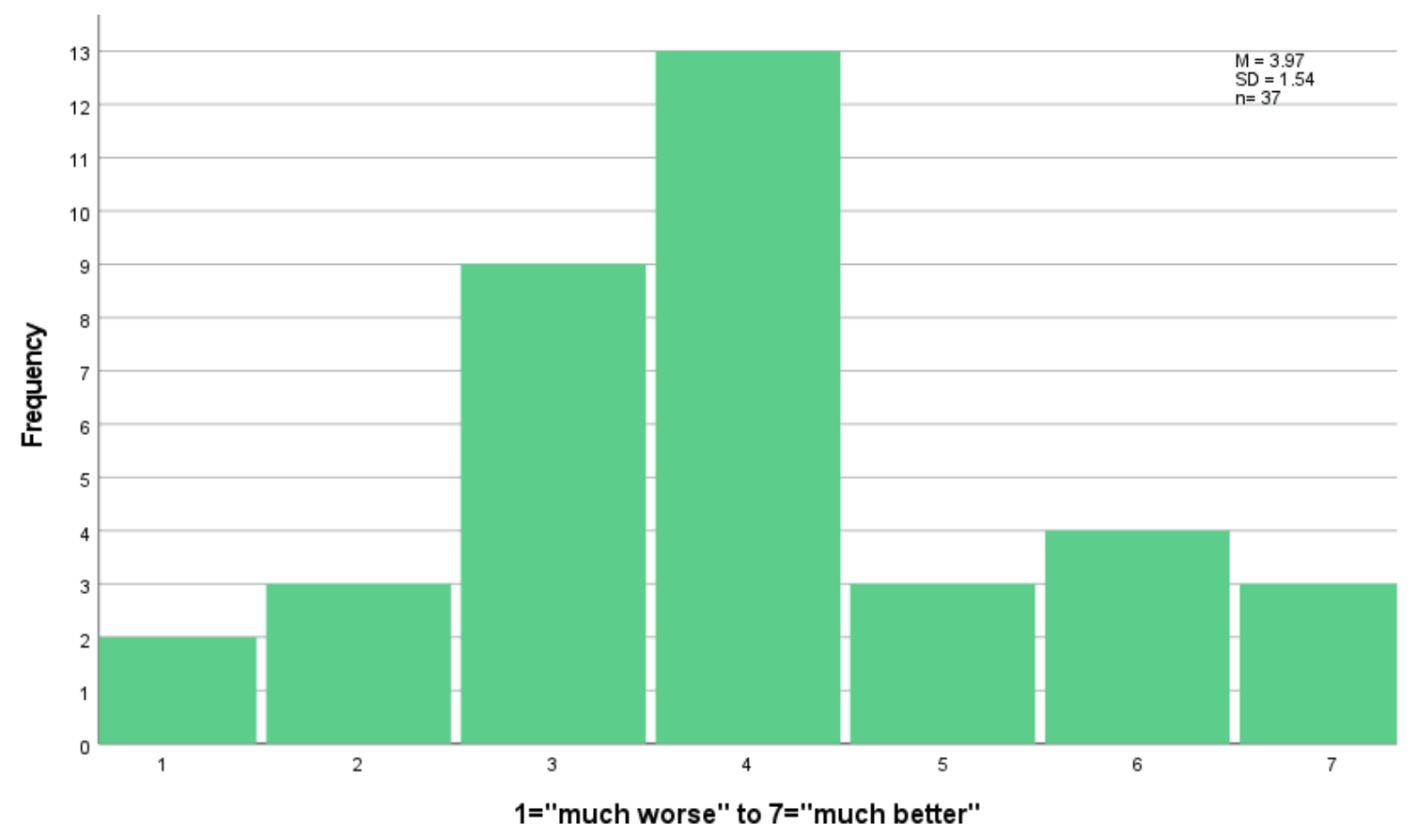

Figure 4. Quality assessment of regional reed as compared to other sources on a Likert-scale by responding thatching companies in Northern Germany $(n=37)$. 


\subsection{Demand for and Promotion of Reed of Regional Origin}

Next to the importance thatching companies assigned to the origin of reed, we also asked for the demand on the part of building owners. The thatchers stated that on average $34 \%$ of their customers asked for reed of regional origin on their own $(n=45)$. Thatching companies with own reed harvest $(n=4)$ indicated a much higher demand shown by on average $75 \%$ of their customers. In the case of $29 \%$ of all thatching companies, no customer asked for thatching reed of regional origin (Figure 5).

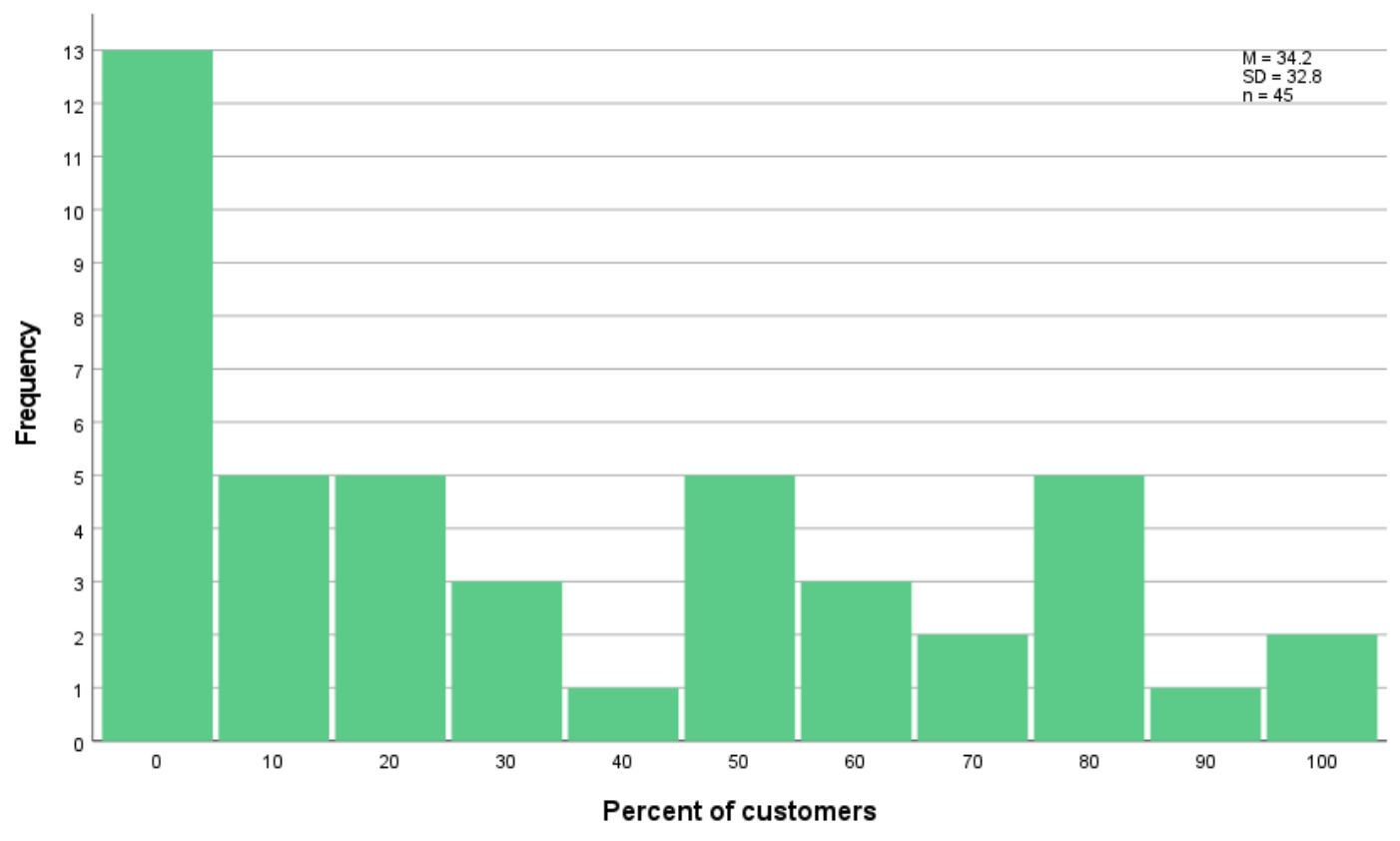

Figure 5. Percent of customers asking for thatching reed of regional origin on their own in responding thatching companies in Northern Germany $(n=45)$.

Assuming that the share of customers demanding regional reed approximates the share of demanded reed bundles, the before mentioned information can be used to calculate the market potential for reed of regional origin. For the sample of 35 respondents, the latent demand is estimated at 256,846 bundles. Compared to the number of bundles of German origin used for thatching in 2018 (126,594 bundles), this indicates an excess demand and a supply gap for reed of regional origin.

When asked whether thatchers or their employees promote reed of regional origin to their customers only $30 \%$ responded that they did $(n=46)$. For the thatchers denying the promotion of regional reed, the most common reason was an insufficient supply $(50 \%)$ and the second one the poor quality of reed of regional origin $(31 \%)(n=31)$. The quality deficiencies specified consider too short and/or too soft reed $(n=4)$. All reasons given by thatchers for not promoting reed of regional origin are listed in the original wording in Appendix A Table A1.

Table 6 shows that the perceived quality of reed has an impact on the promotion of regional reed. A Fisher's Exact test showed a significant correlation between the promotion of regional reed and the assessment of the quality of reed of regional origin compared to reed from other sources $(p=0.002$; $\mathrm{n}=36)$.

Despite the reed of regional origin being perceived as inferior in some cases, $69 \%$ of thatchers who have so far not promoted reed of regional origin would generally be willing to offer more of it, $15 \%$ would be unwilling to do so, and $15 \%$ had no opinion on this question $(n=32)$. Of the thatchers who already promoted regional reed, $86 \%$ would be willing to offer even more and $14 \%$ had no opinion on the subject $(\mathrm{n}=14)$. 
Table 6. Relationship between quality assessment and promotion of thatching reed by responding thatching companies in Northern Germany.

\begin{tabular}{ccccc}
\hline \multirow{2}{*}{$\begin{array}{c}\text { Promotion of Thatching } \\
\text { Reed of Regional Origin }\end{array}$} & \multicolumn{2}{c}{$\begin{array}{c}\text { Quality Assessment of Regional Reed } \\
\text { Compared to Other Sources }\end{array}$} & \multirow{2}{*}{ Total } \\
\cline { 2 - 4 } & Worse & Same & Better & \\
\hline Yes & 0 & 8 & 3 & 11 \\
No & 13 & 5 & 7 & 25 \\
Total & 13 & 13 & 10 & 36 \\
\hline
\end{tabular}

\subsection{Supply of Reed of Regional Origin}

In order to check whether the supply of reed of regional origin is large enough to meet the current demand, the thatchers were asked whether sufficient reed of regional origin was available. Of the respondents ( $n=45), 36 \%$ stated to have sufficient thatch of regional origin available, while $64 \%$ stated that the available thatch could not cover their orders. After a qualitative evaluation, the thatchers gave eight reasons why the demand for reed of regional origin could not have been met. The most common reason (23\% of the respondents) was "Too little reed beds/declining stocks", "Nature conservation", and "No offer" ( $\mathrm{n}=28)$. All reasons given by the thatchers are listed as quotes in Appendix A Table A2.

According to the survey, four companies $(8.5 \%)$ conduct reed harvesting $(n=4)$ in Northern Germany. Of the other companies, $12(25.5 \%)$ harvested reed in former timers but gave it up in the 60 s or $70 s(n=3), 80$ s or $90 s(n=3)$, or since $2000(n=6)$. One of the companies currently harvesting reed is located in Lower Saxony, two of the companies in Mecklenburg-Western Pomerania and one company in Schleswig-Holstein. The company in Lower Saxony also cultivated reed for this purpose, the other three harvested only existing natural reed beds. The companies that conducted own reed harvesting harvested a total of 54,256 bundles $(M=13,564, S D=21,274)$ of reed in winter $2017 / 2018$ (harvest period for 2018), of which 45,456 bundles (84\%) were harvested by the company in Lower Saxony. Two of the companies did not state how many Euro bundle of reed they installed in total in 2018. In one of the companies the self-harvested bundles accounted for $10 \%$ of the total bundles installed, in the other the installed bundles only made up $40 \%$ of the self-harvested bundles.

\subsection{Extrapolation of the Market Volume and the Markt Potential for Reed of Regional Origin}

Based on the survey information, the results were extrapolated to the entire thatching market in Northern Germany. The focus was on the quantity and value of thatching reed and the market share and market potential for regional reed. According to the Kruskal-Wallis test, the hypothesis that distribution of all above reported variables are identical between Schleswig-Holstein, Lower Saxony, and Mecklenburg-Western Pomerania could not be rejected, except for three variables. These were the number of orders for renewed roofs and repairs and the price for thatch of non-German origin. Therefore, we consider it as justifiable to perform a simple extrapolation instead of a weighted one, assuming the whole sample distribution to represent the entire population (Table 7). The extrapolated point estimates are presented together with the $95 \%$ confidence intervals. Because the share of reed of German origin of $17 \%$ could be verified by external sources (see Section 3.4), the market share was taken as certain. All other variables were subjected to a calculation of sampling errors, i.e., estimating how far the population mean is likely to be from the sample mean.

Thus, we estimated a market volume of $3 \pm 0.8$ million bundles of reed in Northern Germany, where the majority of reed is installed by companies located in Schleswig-Holstein, followed by Mecklenburg-Western Pomerania, and Lower Saxony. The total market value of reed in sales prices is estimated at $€ 11.6 \pm 2.8$ million. 
Table 7. Estimated market volume and market potential of reed of regional origin in Northern Germany in $2018(\mathrm{~N}=141)$.

\begin{tabular}{|c|c|c|c|}
\hline Item & Indicator, Unit & Calculation $^{b}$ & Northern German Market ${ }^{b, c}$ \\
\hline \multirow{2}{*}{ Market volume } & Reed bundles ${ }^{\mathrm{a}}$, number & 141 companies $\times 21,445 \pm 5755$ bundles per company & $3,024,000 \pm 811,000$ \\
\hline & Value, $€$ & $\begin{array}{c}\text { Reed bundles of non-German origin } \times € 3.90 \pm 0.3 \text { per reed bundle }+ \text { reed } \\
\text { bundles of German origin } \times € 3.57 \pm 0.3 \text { per reed bundle }\end{array}$ & $11,624,000 \pm 2,756,000$ \\
\hline \multirow{2}{*}{$\begin{array}{l}\text { Market volume for reed of } \\
\text { regional or German origin }\end{array}$} & Reed bundles, number & $\begin{array}{c}141 \text { companies } \times 21,445 \pm 5755 \text { bundles per company } \times \text { share of reed of } \\
\text { regional or German origin }(0.17)\end{array}$ & $511,000 \pm 137,000$ \\
\hline & Value, $€$ & Reed bundles of regional or German origin $\times € 3.57 \pm 0.3$ per reed bundle & $1,824,000 \pm 515,000$ \\
\hline \multirow{2}{*}{$\begin{array}{l}\text { Market potential for reed of } \\
\text { regional or German origin }\end{array}$} & Reed bundles, number & $\begin{array}{c}\text { Share of customers demanding reed of regional origin }(0.34 \pm 0.08) \times \\
\text { total number of reed bundles }\end{array}$ & $1,034,000 \pm 367,000$ \\
\hline & Value, $€$ & $\begin{array}{l}\text { Market potential for reed of regional or German origin in reed bundles } \times \\
\qquad 3.57 \pm 0.3 \text { per reed bundle }\end{array}$ & $3,692,000 \pm 1,348,000$ \\
\hline \multirow{2}{*}{$\begin{array}{l}\text { Excess demand or Supply gap for } \\
\text { reed of regional or German origin }\end{array}$} & Reed bundles, number & $\begin{array}{c}\text { Market potential for reed of regional or German origin-respective actual } \\
\text { market volume }\end{array}$ & $523,000 \pm 392,000$ \\
\hline & Value, $€$ & $\begin{array}{c}\text { Value of the market potential for reed of regional or German } \\
\text { origin-respective actual market value }\end{array}$ & $1,867,000 \pm 1,407,000$ \\
\hline
\end{tabular}


The market volume for regional or German reed in Northern Germany is estimated at $511,000 \pm 137,000$ bundles and at a market value of $€ 1.8 \pm 0.5$ million. The market potential, however, is much higher as the final demand for regional reed suggests. Thus, we estimated a supply gap for reed of regional or German origin of $523,000 \pm 392,000$ bundles or $€ 1.9 \pm 1.4$ million. If supplied at current quality and prices it is estimated that on average more than double the bundles could have been sold. However, these estimates are connected with substantial uncertainty.

\section{Discussion}

Thatchers are decisive actors in the reed value chain being responsible for both purchasing reed and thatching roofs for the house owners. Our survey among thatchers provides the first in-depth analysis of the market for thatching reed in Northern Germany. We determined the market volume of thatching reed in Northern Germany and assessed the market potential for reed of regional origin in quantitative and qualitative terms.

\subsection{Current State and Development of the Reed Market in Northern Germany}

For answering the first research question, we estimated the total market volume for thatching reed in Northern Germany and analyzed the market volume for the three different thatching services identified: (1) newly build roofs, (2) renewal, and (3) repair of existing roofs. The total market volume was estimated at around $3 \pm 0.8$ million bundles of reed with a monetary value at sales prices of $€ 11.6 \pm 2.8$ million in 2018. These figures are an extrapolation, which is to be viewed under the fact that there were large differences between the surveyed companies. Few literature is available to verify the extrapolation.

The EU trade statistics depict general trends and interannual differences in reed trade between countries [15] but appear unsuitable for cross validation of the total market volume (in bundles) for a specific year. According to the extrapolated survey data about $2.5 \pm 0.7$ million bundles were imported. Converting the imports of 6367 tons of reed reported in EU trade statistic into bundles (assuming average weights of $4 \mathrm{~kg}$, based on $3.2 \mathrm{~kg}$ dry mass per bundle (range: 2.4-5 kg) [43] and $15-18 \%$ water content in traded bundles) resulted in about 1.5 million bundles. The difference amounts to almost 1 million bundles for the point estimate and 0.3 to 1.7 million bundles for the $95 \%$ confidence interval. That reed quantities are not completely pictured by EU trade statistics may be linked to observation gaps for goods traded between EU member states, e.g., due to Intrastat reporting exemption thresholds [44]. Furthermore, bundles have a standard value for the circumference but not for the mass. Long $(>1.90 \mathrm{~m})$, medium long $(>1.40 \mathrm{~m})$, and short bundles are distinguished [25]. Extreme droughts experienced in Europe in 2016/2017 [45] may have affected the reed growth and led to shorter bundles with lower weight traded in 2018. Finally, reed may be stored and the year of purchase and of thatching may differ.

The calculated total market volume of $3 \pm 0.8$ million reed bundles, however, equals an earlier estimate of 3 million bundles made by the Society for reed quality assurance (QSR), which was based on information provided by reed traders [11]. Wichmann and Köbbing [15] identified further similar estimates of 2-3 million bundles for single periods between 1990 and 2013. A considerably higher value of 4.8 million bundles of reed needed per year in Northern Germany was mentioned in 1996 by the chairman of the thatcher guild Mecklenburg-Western Pomerania and published in Schäfer [46]. Fluctuations between the years [46] are mentioned as well as a decline of the reed market at the beginning of the 21st century due to observed cases of early decay of thatched roofs [11]. The recovery of the reed market stated by QSR [11] seems to have continued since the results of our survey suggest a slightly increased demand for thatching newly built houses in Northern Germany in the past 10 years (2008-2018). According to the conducted linear regression, the responding thatchers used only $24 \%$ of the reed for newly constructed roofs in 2018 , but $59 \%$ for completely renewed roofs, and $17 \%$ for roof repairs. It is unknown, however, how many thatched roofs exist in Germany [11]. Furthermore, it cannot be assessed whether the number of thatched roofs increases due to newly built houses or 
decreases due to thatched houses being demolished or covered with a hard roof at the end of the lifetime of the soft thatched roof.

\subsection{Origins of Reed and Development of Market Shares}

The second research question addresses the origin of the reed used for thatching in Northern Germany. The survey results clearly show that most of the reed is imported from the European market $(67 \%)$ and from China (16\%). Only 17\% of the reed bundles are from Germany. The calculated import shares were confirmed by EU trade statistics reporting $66 \%$ of reed imported from the European market and $17 \%$ from China. In an overview study of the European reed market, an import rate fluctuating around 80\% from 1990 to 2013 was reported for Germany [15]. The import rate of 83\% revealed by the survey fits well to these literature values. Imports continue to be at a high level and even might have increased slightly.

\subsection{The Potential of Reed of Regional Origin}

The third research question focuses on the market of reed of regional origin and factors influencing the demand and supply. The majority of the responding thatchers relates the term "regional" to their own federal state $(28 \%)$ or even to their own district $(26 \%)$. German reed is considered as being "regional" only by 33\% of the respondents. Most of the German reed used by thatchers is indeed from their specific federal state (Table 3). The thatchers also indicated that on average a third of their customers asked about reed of regional origin, but the range was as wide as possible reaching from 0 to $100 \%$. According to the extrapolation, the current market volume of reed from Germany is $511,000 \pm 137,000$ bundles with a monetary value of $€ 1.8 \pm 0.5$ million. The market potential, based on the share of costumers asking for regional reed on their own, is about double $(1 \pm 0.4$ million bundles, $€ 3.7 \pm 1.4$ million), indicating an excess demand of $523,000 \pm 392,000$ bundles ( $€ 1.9 \pm 1.4$ million) not met by the current supply. Assuming an average yield of 500 bundles per hectare [19], this latent demand can be covered by an additional harvest area of $1046 \pm 784$ ha. Considering that $70 \%$ of the responding thatchers do not promote reed of regional origin, the potential market for reed of regional origin can be larger than calculated. The majority of thatchers who have not yet promoted reed of regional origin would generally be willing to do so $(69 \%)$. The unavailability of regional reed was mentioned by $50 \%$ as the reason for not promoting regional reed and insufficient quality by $31 \%$. Surprisingly, thatching reed from Germany is offered at a significant slightly lower price despite of the demand exceeding the supply. This result might indicate that although regional reed is preferred, final consumers are not willing to pay a higher price. Furthermore, lower prices might be connected with lower quality [47]. Quality issues were repeatedly reported by the surveyed thatchers as reasons for not promoting regional reed or for the inability to supply the demand of customers (see Tables A1 and A2). Nevertheless, thatchers were quite divided in their assessments and some consider regional reed as of superior quality (see Figure 4). In particular, thatchers who harvest reed were convinced of the superior quality. Although there is some scientific literature on the quality of reed for thatching from different provinces, the results show the huge variability and are overall inconclusive about the quality of reed of different origins $[48,49]$.

\subsection{Potential and Obstacles of Cultivating Reed}

It can be concluded that there is a demand for more and above all more high-quality reed of regional origin. Cultivating reed may improve both quantity and quality of regional reed for thatching. Thus, cultivating thatching reed is one promising and climate-smart alternative to drained agricultural peatlands. Growing reed on rewetted peatlands can generate climate benefits in several ways: (a) minimizing $\mathrm{CO}_{2}$ emissions from peat oxidation [50], (b) acting as strong $\mathrm{CO}_{2}$ sink [51] due to carbon-capture and long-term storage in belowground biomass and peat formation, (c) using reed for replacing fossil resources, e.g., avoided emissions caused by energy use in roof tile production, and (d) (temporal) carbon-capture and storage if harvested aboveground biomass is used as long-life building material. 
In terms of area demand, however, $6000 \pm 1600$ ha with an average yield of 500 bundles per hectare [15] would be sufficient to produce even all $3 \pm 0.8$ million bundles of the current total market. Considering a surplus area, e.g., for buffering for harvest failures, a maximum area of 10,000 ha is needed. Applying national GHG emission factors (including emission of $\mathrm{CO}_{2}, \mathrm{CH}_{4}, \mathrm{~N}_{2} \mathrm{O}$ ) for drained cropland (40.4 $\mathrm{t} \mathrm{CO}_{2}$-eq.), drained grassland (31.7 $\mathrm{t} \mathrm{CO}_{2}$-eq.) and rewetted sites (5.5 $\mathrm{t} \mathrm{CO}_{2}$-eq [52]), the annual saving due to minimized peat oxidation for 10,000 ha could be 260,000 to $350,000 \mathrm{t} \mathrm{CO}_{2}$-eq. In relation to total emissions of about $45 \mathrm{Mio} \mathrm{t} \mathrm{CO}_{2}$-eq from agricultural used drained peatlands in Germany [52], this saving can only be a small component. Other biomass utilization options and further crops need to be investigated to provide economically viable paludiculture options [19] for about 383,000 ha of arable land and 852,000 ha of grassland on drained organic soils [53] in Germany.

The cultivation of reed may range from shifting the harvest season from summer to winter, over improved water management, the planting of pre-cultivated seedlings for stand establishment, up to the selection of provenances, genotypes, or even breeding for improved reed quality. So far, winter harvested reed stands in Germany are not eligible for direct payment under the EU Common Agricultural Policy [54]. Therefore, it is not surprising that reed cutters report wet grassland to be mown by the land manager in summer (and thus impeding a winter harvest for thatching) just for generating EU subsidies despite of a lack of utilization for the biomass. Negotiations on the new CAP post 2020 include proposals for considering paludiculture as eligible for agricultural payments in the future, which would eliminate a major obstacle of reed cultivation. Another factor is the need for special harvesting equipment adapted to the low bearing capacity of reed stands and equipped with a specific mowing (and cleaning) device [55]. The purchase of such a machine is economically feasible only with a certain minimum size of harvesting area. Our results showed, however, that the current reed harvesting area is limited (Table A2: not available, too small, very restricted use, nature conservation). Several pilot trials proved the feasibility of planting reed for establishing a reed stand in Great Britain [56], the Netherlands [16], and Germany [57,58], and practical experience of the commercial harvest of planted reed stands is available. Research on how to achieve and improve thatching qualities of reed cultivated on rewetted peatlands is still in progress.

\subsection{Limitations of the Study}

When evaluating the results and the extrapolation, it should be kept in mind that with a participation rate of $33 \%$, the situation of 94 thatching companies in Northern Germany remains unknown. It should also be noted that due to individual unanswered questions, the response rate of $33 \%$ was not met for all questions. These nonresponses reduced the effective sample size and unavoidably increased the sampling error. Based on the assumption that nonresponses were completely random, confidence intervals for major extrapolated variables could be computed. However, nonsampling errors might have occurred. The participation was determined by the willingness of the thatchers to take part in the survey. It is conceivable that responses were given by larger companies that had the human resources or by thatchers who were already interested in the topic of "regionality". This was attempted to be reduced by avoiding the topic of regionality at the beginning and in the cover letter of the questionnaire. Overall, it can be concluded that, based on the target group and the survey design, a response rate of $33 \%$ represents a satisfactory effective sample size suitable to make valid statements, which was demonstrated by the comparison with trade data and literature values. It can therefore be assumed that despite all uncertainties, overall a good overview of the market for reed in Northern Germany could be given. Limitations concern the concept of "regional reed", which may be defined differently by thatchers and house owners. In addition, the question on prices paid for a reed bundle by the end consumer lacks a specification on gross and net values so that the stated prices must be viewed with caution. In conclusion, it is pointed out that the present work is limited to the perspective of thatchers. Addressing further actors of the reed value chain such as reed cutters, traders of thatching reed, or the owners of thatched house can provide further insights into the reed market. 


\section{Conclusions}

The results provide a detailed picture of the reed market in Northern Germany and quantify the market potential for reed of regional origin. The lacking supply of regional reed concerns not only the quantity but also the quality. The survey revealed a further decline in domestic reed harvesting and conflicts with nature conservation targets. Considering the large areas of drained peatlands and wetlands used for agriculture, rewetting already a very small share of it for reed cultivation would allow to improve the regional availability of reed as traditional ecological roofing material and simultaneously reduce GHG emissions. Further investigations are needed on the quality of reed cultivated in paludiculture. A similar situation can be assumed for other European countries, as the Netherlands, the UK, and Denmark, which share the tradition of thatching houses with reed, have large areas of drained wetlands and import up to $85 \%$ of their reed.

Author Contributions: Conceptualization, L.B., S.W. and V.B.; methodology, L.B., S.W. and V.B.; validation, L.B. S.W. and V.B.; formal analysis, L.B., V.B.; investigation, L.B.; resources, S.W., V.B.; data curation, L.B., S.W., V.B.; writing-original draft preparation, L.B., V.B. and S.W.; writing-review and editing, S.W., V.B.; visualization, S.W., V.B.; supervision, S.W., V.B.; project administration, S.W.; funding acquisition, S.W., V.B. All authors have read and agreed to the published version of the manuscript.

Funding: This research was funded by Bundesministerium für Ernährung und Landwirtschaft | Fachagentur Nachwachsende Rohstoffe, grant number FKZ 22026017.

Acknowledgments: We thank all thatchers for participating in the survey and Stephan Busse for creating the map on sampled and responding thatching companies.

Conflicts of Interest: The authors declare no conflict of interest.

\section{Appendix A}

Table A1. Reasons why reed of regional origin was not promoted, full answers.

\begin{tabular}{|c|c|}
\hline Participant ID & Response \\
\hline 1 & Too little available, culm length too short (hearsay) \\
\hline 2 & Quality is sometimes not sufficient \\
\hline 3 & Quality is worse than reed from Ukraine and China \\
\hline 4 & Because thatch from other countries is also good, but should be in the same latitude \\
\hline 9 & Because it is not available \\
\hline 11 & Amount offered too small \\
\hline 12 & Too few with good quality available \\
\hline 13 & Because there is hardly anything and because the greens throw us sticks between the legs \\
\hline 14 & Quality is comparable, and the price is more important to the customer \\
\hline 16 & Most of the reed goes to Holland, the rest is personal consumption \\
\hline 17 & $\begin{array}{l}\text { It does not depend on the origin, but on the usability on the respective roof or on the } \\
\text { respective conditions }\end{array}$ \\
\hline 19 & Insufficient quantity available \\
\hline 20 & Because not enough reed comes from Germany \\
\hline 21 & There is hardly any local thatch, so I cannot promote it \\
\hline 23 & Nothing on the market, not available \\
\hline 24 & Unfortunately no longer-product data sheet \\
\hline 25 & There is too little \\
\hline 27 & In principle, it is only available to a very limited extent \\
\hline 28 & Does not meet my expectations, mostly too short and very soft \\
\hline 30 & Too little regional reed \\
\hline
\end{tabular}


Table A1. Cont.

\begin{tabular}{cc}
\hline Participant ID & Response \\
\hline 32 & Since there is no thatch on the market! \\
\hline 34 & Because there is none \\
\hline 35 & I don't have a supplier/trader for regional reed \\
\hline 37 & Not good quality \\
\hline 38 & Because the quality of reed bundles has not been satisfactory in recent years \\
\hline 41 & Because German reed that grows up in the Weser river in algae and reed from S-H is \\
\hline 43 & too soft. \\
\hline 47 & Too much effort \\
\hline
\end{tabular}

Note: Only those participants are listed who have given an answer.

Table A2. Reasons why there wasn't enough reed of regional origin to meet demand, full answers.

\begin{tabular}{|c|c|}
\hline Participant ID & Response \\
\hline 1 & Not enough harvesting areas, nature conservation \\
\hline 4 & Because too little thatch is harvested in Germany \\
\hline 8 & Depends on the size of the building and staff (construction project) \\
\hline 12 & $\begin{array}{l}\text { A lot of regional thatch is not offered in the quality that it meets the "technical rules for } \\
\text { roofing with thatch" }\end{array}$ \\
\hline 13 & $\begin{array}{l}\text { 1. You have to apply for harvesting permits } 1 \text { year in advance } 2 \text {. You then don't know } \\
\text { whether it is possible to mow (frost). What then: } 3 \text {. would be throwing money out of the } \\
\text { window. } 4 \text {. It is very difficult to meet the requirements }\end{array}$ \\
\hline 15 & Not enough areas for harvesting \\
\hline 17 & $\begin{array}{l}\text { Applies to us, not to the industry. Not enough reed is allowed to be harvested for the entire } \\
\text { needs of the regional branch. }\end{array}$ \\
\hline 19 & Insufficient area available or no harvesters \\
\hline 20 & Because too little is harvested or not enough \\
\hline 21 & There is only one person cultivating reed here and the amount is limited \\
\hline 23 & Nothing on the market, not available \\
\hline 24 & Rent too high for German thatchers \\
\hline 25 & Politically that is probably what is wanted \\
\hline 27 & $\begin{array}{c}\text { Existing reed beds (areas) may only be used very restrictively, see guidelines for reed } \\
\text { harvesting in MV }\end{array}$ \\
\hline 28 & No or too small harvest areas $->$ NABU and nature conservation \\
\hline 30 & There is not enough regional thatch on the market \\
\hline 31 & Too little land to harvest \\
\hline 32 & Because hardly any thatch is harvested! \\
\hline 34 & The reed beds have declined sharply \\
\hline 35 & Don't know who is supplying me with it \\
\hline 38 & Because there is too little land for harvesting \\
\hline 39 & Because more and more "falls" towards nature conservation \\
\hline
\end{tabular}


Table A2. Cont.

\begin{tabular}{cc}
\hline Participant ID & Response \\
\hline 40 & Too little reed harvesting \\
\hline 41 & Location dependent \\
\hline 42 & Hardly or not at all offered by traders \\
\hline 43 & $\begin{array}{c}\text { There are only small quantities of good quality-you have to secure a batch quickly or in } \\
\text { due time. Often the required quantity is only sufficient for 1-2 orders for new roofs. }\end{array}$ \\
\hline 47 & Areas are banned or not redistributed-stock is decreasing \\
\hline
\end{tabular}

\section{References}

1. Rodewald-Rudescu, L. Das Schilfrohr. (Phragmites Communis Trinus); Schweizerbart: Stuttgart, Germany, 1974; ISBN 9783510400386.

2. Haslam, S.M. A Book of Reed: (Phragmites Australis (Cav.) Trin. ex Steudel, Phragmites Communis Trin.); Forrest Text: Cardigan, UK, 2010; ISBN 978-0-9564692-0-5.

3. Kiviat, E. Ecosystem services of Phragmites in North America with emphasis on habitat functions. AoB Plants 2013, 5, plt008. [CrossRef]

4. Köbbing, J.F.; Thevs, N.; Zerbe, S. The utilisation of reed (Phragmites australis): A review. Mires Peat 2013, 13, 1-14.

5. Brix, H.; Ye, S.; Laws, E.A.; Sun, D.; Li, G.; Ding, X.; Yuan, H.; Zhao, G.; Wang, J.; Pei, S. Large-scale management of common reed, Phragmites australis, for paper production: A case study from the Liaohe Delta, China. Ecol. Eng. 2014, 73, 760-769. [CrossRef]

6. Köbbing, J.F.; Beckmann, V.; Thevs, N.; Peng, H.; Zerbe, S. Investigation of a traditional reed economy (Phragmites australis) under threat: Pulp and paper market, values and Netchain at Wuliangsuhai Lake, Inner Mongolia, China. Wetl. Ecol. Manag. 2016, 24, 357-371. [CrossRef]

7. Schattke, W. Das Reetdach. Natürliches Wohnen unter Sanftem Dach—von der Urzeit bis Heute, 3. Aufl.; Christians Verlag: Hamburg, Germany, 1992; ISBN 3-7672-1140-8.

8. German UNESCO Commission. German Inventory of Intangible Cultural Heritage; German UNESCO Commission: Bonn, Germany, 2019; ISBN 978-3-940785-97-8.

9. Deutsche UNESCO-Kommission. Reetdachdecker-Handwerk. Available online: https://www.unesco.de/kult ur-und-natur/immaterielles-kulturerbe/immaterielles-kulturerbe-deutschland/bundesweites-43 (accessed on 9 April 2020).

10. Haslam, S.M. Early decay of Phragmites thatch: An outline of the problem. Aquat. Bot. 1989, 35, $129-132$. [CrossRef]

11. QSR-Gesellschaft zur Qualitätssicherung Reet mbH. Reet als Dacheindeckungsmaterial Qualitätssicherung und -Erhaltung eines Baustoffs aus Nachwachsenden Rohstoffen. Bericht zum Forschungsvorhaben der Deutschen Bundesstiftung Umwelt. 2008. Available online: https://www.dbu.de/OPAC/ab/DBU-Abschlussbericht-AZ-2 5018.pdf (accessed on 14 December 2020).

12. Schrader, M. Reet E Stroh als historisches Baumaterial. Ein Materialleitfaden und Ratgeber; Anderweit Verlag GmbH: Suderburg-Hösseringen, Germany, 1998.

13. Bartels, O. Das Scheunentrio von Prerow. Ausgezeichnete Baukultur mit Vorbildcharakter. Deutsches Architektenblatt 2014, 9, 23-25. Available online: https://www.architektenkammer-mv.de/media/dab-ausgab en-2014/dab-mv-09-14final.pdf (accessed on 14 December 2020).

14. The Contemporist. 12 Examples of Modern Houses and Buildings That Have a Thatched Roof. Available online: https://www.contemporist.com/modern-houses-that-have-thatched-roof/ (accessed on 14 December 2020).

15. Wichmann, S.; Köbbing, J.F. Common reed for thatching-A first review of the European market. Ind. Crop. Prod. 2015, 77, 1063-1073. [CrossRef] 
16. Geurts, J.J.M.; van Duinen, G.-J.A.; van Belle, J.; Wichmann, S.; Wichtmann, W.; Fritz, C. Recognize the high potential of paludiculture on rewetted peat soils to mitigate climate change: Position Paper. J. Sustain. Org. Agric. Syst. 2019, 69, 5-8.

17. Wichtmann, W.; Schröder, C.; Joosten, H. Paludikultur als integrative Systemlösung. In Paludikultur: Klimaschutz—Biodiversität_Regionale Wertschöpfung; Schweizerbart: Stuttgart, Germany, 2016; pp. 1-2.

18. Greifswald Mire Centre; National University of Ireland Galway; Wetlands International European Association. Peatlands in the EU. Common Agricultural Policy (CAP) after 2020. Position Paper-(Version 4.8). 2020. Available online: https://greifswaldmoor.de/files/dokumente/Infopapiere_Briefings/202003_CAP\%20Policy \%20Brief\%20Peatlands\%20in\%20the\%20new\%20EU\%20Version\%204.8.pdf (accessed on 14 December 2020).

19. Wichmann, S. Commercial viability of paludiculture: A comparison of harvesting reeds for biogas production, direct combustion, and thatching. Ecol. Eng. 2017, 103, 497-505. [CrossRef]

20. Tanneberger, F.; Schröder, C.; Hohlbein, M.; Lenschow, U.; Permien, T.; Wichmann, S.; Wichtmann, W. Climate Change Mitigation through Land Use on Rewetted Peatlands-Cross-Sectoral Spatial Planning for Paludiculture in Northeast Germany. Wetlands 2020. [CrossRef]

21. Tanneberger, F.; Appulo, L.; Ewert, S.; Lakner, S.; Brolcháin, N.Ó.; Peters, J.; Wichtmann, W. The Power of Nature-Based Solutions: How Peatlands Can Help Us to Achieve Key EU Sustainability Objectives. Adv. Sustain. Syst. 2020, 2000146. [CrossRef]

22. Hellin, J.; Meijer, M. Guidelines for Value Chain Analysis. 2006. Available online: http://www.fao.org/ fileadmin/templates/esa/LISFAME/Documents/Ecuador/value_chain_methodology_EN.pdf (accessed on 14 December 2020).

23. Zamora, E.A. Value Chain Analysis: A Brief Review. Asian J. Innov. Policy 2016, 5, 116-128. [CrossRef]

24. Teuber, R. Geographical Indications of Origin as a Tool of Product Differentiation: The Case of Coffee. J. Int. Food Agribus. Mark. 2010, 22, 277-298. [CrossRef]

25. Zentralverband des Deutschen Dachdeckerhandwerks-Fachverband. Produktdatenblatt für Reet, 12th ed.; Verlagsgesellschaft Rudolf Müller GmbH \& Co. KG.: Köln, Germany, 2019; ISBN 978-3-481-03993-6.

26. Wirthgen, A. Consumer, retailer, and producer assessments of product differentiation according to regional origin and process quality. Agribusiness 2005, 21, 191-211. [CrossRef]

27. Hague, P.; Harrison, M.; Cupman, J.; Truman, O. Market Research in Practice. An Introduction to Gaining Greater Market Insight, 3rd ed.; Kogan Page: London, UK, 2016; ISBN 9780749475864.

28. Baur, N.; Blasius, J. (Eds.) Handbuch Methoden der Empirischen Sozialforschung; Springer Fachmedien Wiesbaden; Springer: Wiesbaden, Germany, 2019; ISBN 978-3-658-21308-4.

29. Groves, R.M.; Fowler, F.J.; Couper, M.; Lepkowski, J.M.; Singer, E.; Tourangeau, R. Survey Methodology, 2nd ed.; Wiley: Hoboken, NJ, USA, 2009; ISBN 9780470465462.

30. Schnell, R.; Hill, P.B.; Esser, E. Methoden der Empirischen Sozialforschung, 8., unveränd. Aufl.; Oldenbourg: München, Germany, 2008; ISBN 9783486587081.

31. Särndal, C.-E.; Lundström, S. Estimation in Surveys with Nonresponse; Wiley: Hoboken, NJ, USA, 2005; ISBN 9780470011331.

32. Siebert, C.F.; Siebert, D.C. Data Analysis with Small Samples and Non-Normal Data. Nonparametrics and Other Strategies; Oxford University Press: New York, NY, USA, 2018; ISBN 9780199391509.

33. Janssen, J.; Laatz, W. Statistische Datenanalyse mit SPSS, 9th ed.; Springer Gabler: Berlin/Heidelberg, Germany, 2017.

34. Rea, L.M.; Parker, R.A. Designing and Conducting Survey Research. A Comprehensive Guide, 4th ed.; Jossey-Bass: San Francisco, CA, USA, 2014; ISBN 9781118767030.

35. Hughes, I.; Hase, T.P.A. Measurements and Their Uncertainties. A Practical Guide to Modern Error Analysis; Oxford University Press: Oxford, UK, 2010; ISBN 1282732269.

36. Mayring, P. Qualitative Inhaltsanalyse. Grundlagen und Techniken, 12., überarb. Aufl.; Beltz: Weinheim, Germany, 2015; ISBN 3407257309.

37. Wirtz, M.; Kutschmann, M. Analyzing Interrater Agreement for Categorical Data Using Cohen's Kappa and Alternative Coefficients. Rehabilitation 2007, 46, 370-377. [CrossRef] [PubMed]

38. Landis, J.R.; Koch, G.G. The Measurement of Observer Agreement for Categorical Data. Biometrics 1977, 33, 159-174. [CrossRef]

39. European Union. Eurostat. Available online: https://ec.europa.eu/eurostat/web/international-trade-in-goods /data/database (accessed on 28 October 2020). 
40. MeinDach GmbH. Mein Dach. Available online: https://www.meindach.de/ratgeber/was-kostet-ein-dach/ (accessed on 17 April 2020).

41. Reetdachdeckerei Ohm. o.T. Available online: https://www.reetdachdeckerei-ohm.de/reetdach.html (accessed on 17 April 2020).

42. Zentralverband des Deutschen Dachdeckerhandwerks-Fachverband. Fachregeln für Dachdeckungen mit Reet, 12th ed.; Verlagsgesellschaft Rudolf Müller GmbH \& Co. KG.: Köln, Germany, 2019.

43. Dahms, T.; Oehmke, C.; Kowatsch, A.; Abel, S.; Wichmann, S.; Wichtmann, W.; Schröder, C. Halmgutartige Festbrennstoffe aus Nassen Mooren. Paludi-Pellets-Broschüre; Universität Greifswald: Greifswald, Germany, 2017.

44. European Union. National Requirements for the Intrastat System, 2018 ed. 2017. Available online: https://ec.europa.eu /eurostat/documents/3859598/8512202/KS-07-17-102-EN-N.pdf/736c4a50-c240-4144-b087-4fa6aece8ee0 (accessed on 14 December 2020).

45. García-Herrera, R.; Garrido-Perez, J.M.; Barriopedro, D.; Ordóñez, C.; Vicente-Serrano, S.M.; Nieto, R.; Gimeno, L.; Sorí, R.; Yiou, P. The European 2016/17 Drought. J. Clim. 2019, 32, 3169-3187. [CrossRef]

46. Schäfer, A. Schilfrohrkultur auf Niedermooren-Rentabilität des Anbaus und der Ernte von Phragmites Australis. Archiv für Naturschutz und Landschaftsforschung 1999, 38, 193-216.

47. Wolinsky, A. Prices as signals of product quality. Rev. Econ. Stud. 1983, 50, 647-658. [CrossRef]

48. Wöhler-Geske, A.; Moschner, C.R.; Gellerich, A.; Militz, H.; Greef, J.-M.; Hartung, E. Provenances and properties of thatching reed (Phragmites australis). Landbauforschung 2016, 66, 1-10.

49. Boar, R.R.; Kirby, J.J.H.; Leeming, D.J. Variations in the quality of the thatching reed Phragmites australis from wetlands in East Anglia, England. Geol. Soc. Lond. Spec. Publ. 1999, 163, 145-151. [CrossRef]

50. Günther, A.; Huth, V.; Jurasinski, G.; Glatzel, S. The effect of biomass harvesting on greenhouse gas emissions from a rewetted temperate fen. GCB Bioenergy 2015, 7, 1092-1106. [CrossRef]

51. Minke, M.; Augustin, J.; Burlo, A.; Yarmashuk, T.; Chuvashova, H.; Thiele, A.; Freibauer, A.; Tikhonov, V.; Hoffmann, M. Water level, vegetation composition, and plant productivity explain greenhouse gas fluxes in temperate cutover fens after inundation. Biogeosciences 2016, 13, 3945-3970. [CrossRef]

52. Tiemeyer, B.; Freibauer, A.; Borraz, E.A.; Augustin, J.; Bechtold, M.; Beetz, S.; Beyer, C.; Ebli, M.; Eickenscheidt, T.; Fiedler, S.; et al. A new methodology for organic soils in national greenhouse gas inventories: Data synthesis, derivation and application. Ecol. Indic. 2020, 109, 105838. [CrossRef]

53. Umweltbundesamt. Berichterstattung unter der Klimarahmenkonvention der Vereinten Nationen und dem Kyoto-Protokoll 2019. Nationaler Inventarbericht zum Deutschen Treibhausinventar 1990-2017; Climate change 23/2019; Umweltbundesamt: Germany, 2019; Available online: https://www.umweltbundesamt.de/publikati onen/berichterstattung-unter-der-klimarahmenkonvention-4 (accessed on 14 December 2020).

54. Kölsch, L.; Witzel, S.; Czybulka, D.; Fock, T. Agricultural policy. In Paludiculture-Productive Use of Wet Peatlands: Climate Protection—biodiversity—Regional Economic Benefits; Wichtmann, W., Schröder, C., Joosten, H., Eds.; Schweizerbart Science Publishers: Stuttgart, Germany, 2016; pp. 149-152, ISBN 9783510652839.

55. Wichmann, S.; Dettmann, S.; Dahms, T. Agricultural machinery for wet areas. In Paludiculture-Productive Use of Wet Peatlands: Climate Protection—Biodiversity—Regional Economic Benefits; Wichtmann, W., Schröder, C., Joosten, H., Eds.; Schweizerbart Science Publishers: Stuttgart, Germany, 2016; pp. 64-70, ISBN 9783510652839.

56. Hawke, C.; José, P. Reedbed Management for Commercial and Wildlife Interests; Royal Society for the Protection of Birds: Sandy, UK, 1996; ISBN 0903138816.

57. Timmermann, T. Anbau von Schilf (Phragmites australis) als ein Weg zur Sanierung von Niedermooren-Eine Fallstudie zu Etablierungsmethoden, Vegetationsentwicklung und Konsequenzen für die Praxis. Archiv für Naturschutz und Landschaftsforschung 1999, 33, 111-143.

58. Tschoeltsch, S. Reet: Vom Anbau bis zum Dach. Das Reetprojekt aus der Eider-Treene-Sorge Niederung; Verein zur Förderung der Kulturlandschaft e.V.: Horstedt, Germany, 2008.

Publisher's Note: MDPI stays neutral with regard to jurisdictional claims in published maps and institutional affiliations. 